\title{
Interactive comment on "Optical and microphysical properties of natural mineral dust and anthropogenic soil dust near dust source regions over Northwestern China" by Xin Wang et al.
}

Xin Wang et al.

wxin@|zu.edu.cn

Received and published: 14 December 2017

\section{Response to Referee \#1}

We are very grateful for the Referee \#1's critical comments and suggestions, which have helped us improve the paper quality substantially. We have addressed all of the comments carefully as detailed below in our point-by-point responses. Our responses start with "R:". 
This study presents the optical and physical properties of anthropogenic soil dust and natural mineral dust near the dust source regions in East Asia. This information is the key to evaluate the impacts of dust on the regional climate. Results and discussions are comprehensive, some valuable information have been generated. I would recommend the paper to be accepted for publication after a few comments as listed below have been addressed.

Interactive

comment

$\mathrm{R}$ : We have addressed all of the comments carefully as detailed below.

I strongly suggest the authors to reorganize the introduction section. The relevant studies on aerosol optical properties over East Asia should be reviewed. Accordingly, significance of this study could be further summarized and focus. For example, page 3 and page 4 all discussed the research importance of dust aerosol rather than their optical properties.

$\mathrm{R}$ : We have constructed the introduction section and added one section in reviewing the aerosol optical properties over East Asia based on previous dust field campaigns.

I suggest the authors to more pay attention to the logics between the sentences and paragraphs. For example, the logic in line 15-22 in page 3 is confusing. Organic matters and sulfate are the dominant chemical compositions of aerosol, why the authors only mentioned BC here?

$\mathrm{R}$ : We agree with the reviewer. For this research mainly discuss the properties of natural and anthropogenic dust near the dust sources regions, we deleted the description of the other air pollutions in the introduction section, such as $\mathrm{BC}, \mathrm{OC}$, and sulfate aerosols.

I also strongly suggest authors to break down the result section into several topics or sections for reading friendly.

$\mathrm{R}$ : We have separated the result section into individual topics based on the reviewer's suggestion. 
I suggest the authors to reorganize the abstract and conclusions due to these two sections are too similar.

$\mathrm{R}$ : The abstract has been rewritten, and the conclusions has been reorganized based on reviewer's suggestions.

The QA/QC of all instruments should be addressed in section 2.2.

R: The QA/QC information for all instruments have been given as Table 1, and the corresponding description is also added in Section 2.2.

Generally, the MAC of BC could be determined by its size distribution and coating. Why authors choose $6.6 \mathrm{~m} 2 \mathrm{~g}-1$ ?

$\mathrm{R}$ : Thanks very much for your comments and suggestions. To convert data into BC mass loadings, a precise knowledge of the mass absorption coefficient (MAC) is of great importance. Actually, a narrow range of BC for MAC (6.4-6.6 m2 g-1) was found to provide a good fit to urban particles collected by previous studies (Petzold et al., 1997; Penner et al., 1998; Sharma et al., 2002; Arnott et al., 2003; Bond and Bergstrom, 2006; Schwarz et al., 2008).

In this study, there are three reasons for us to use this MAC value as follows.

Petzold et al. (2002) obtained the $M A C=6.5 \pm 0.5 \mathrm{~m} 2 \mathrm{~g}-1$ at the wavelength of 670 $\mathrm{nm}$ for the black carbon particles using ambient aerosol samples. The MAAP (Model 5012) provides the absorption information as an equivalent black carbon concentration (EBC), which is obtained by dividing the measured absorption coefficient by a default MAC of 6.6 m2âĂćg-1, recommended by the manufacturer. Müller et al. (2011) found that the optical wavelength of MAAP is $637 \pm 1 \mathrm{~nm}$ instead of $670 \mathrm{~nm}$ during the GAW2005 workshop. For an Ångström exponent of 1.02, the absorption coefficient at $637 \mathrm{~nm}$ should be $5 \%$ higher than that at $670 \mathrm{~nm}$. Hence, the MAC at $637 \mathrm{~nm}$ is $5 \%$ lower and should be corrected by multiplication with a factor of 1.05 , and the corrected equation was given by Müller: " $\sigma$ " _"ap,637" " = " ãĂÚ" m" ãĂŮ_"BC" "âĂć- 
MACâĂć1.05" But we also admit that the BC particles may tend to be mixed with other aerosols during aging process, and the MAC of $B C$ can vary during its lifetime due to changes in its chemical composition. However, it must be noted that our research area is very close to the desert source regions. Therefore, as we used the same MAC value as the MAAP in our calculation, we consider that the variability in MAC as a source of uncertainty can be neglected. Above all, we prefer to use the MAC of BC as $6.6 \mathrm{~m} 2$ $\mathrm{g}-1$ in this study.

References Arnott, W. P., Moosmuller, H., Sheridan, P. J., Ogren, J. A., Raspet, R., Slaton, W. V., Hand, J. L., Kreidenweis, S. M., and Collett, J. L.: Photoacoustic and filter-based ambient aerosol light absorption measurements: Instrument comparisons and the role of relative humidity, J. Geophys. Res-Atmos, 108, 4034, doi:10.1029/2002jd002165, 2003.

Bond, T. C. and Bergstrom, R. W.: Light Absorption by Carbonaceous Particles: An Investigative Review, Aerosol Sci. Tech., 40, 27-67, doi:10.1080/02786820500421521, 2006.

Müller, T., Henzing, J. S., de Leeuw, G., Wiedensohler, A., Alastuey, A., Angelov, H., Bizjak, M., Collaud Coen, M., Engström, J. E., Gruening, C., Hillamo, R., Hoffer, A., Imre, K., Ivanow, P., Jennings, G., Sun, J. Y., Kalivitis, N., Karlsson, H., Komppula, M., Laj, P., Li, S. M., Lunder, C., Marinoni, A., Martins dos Santos, S., Moerman, M., Nowak, A., Ogren, J. A., Petzold, A., Pichon, J. M., Rodriquez, S., Sharma, S., Sheridan, P. J., Teinilä, K., Tuch, T., Viana, M., Virkkula, A., Weingartner, E., Wilhelm, R., and Wang, Y. Q.: Characterization and intercomparison of aerosol absorption photometers: result of two intercomparison workshops, Atmos. Meas. Tech., 4, 245-268, doi:10.5194/amt-4-245-2011, 2011.

Penner, J. E., Chuang, C. C., and Grant, K.: Climate forcing by carbonaceous and sulfate aerosols, Clim. Dynam., 14, 839-851, doi:10.1007/s003820050259, 1998.

Petzold, A., Kopp, C. and Niessner, R.: The Dependence of the Specific Attenuation 
Cross-section on Black Carbon Mass Fraction and Particle Size, Atmos. Environ., 31, 661-672, doi:10.1016/s1352-2310(96)00245-2, 1997.

Petzold, A., Kramer, H., and Schonlinner, M.: Continuous measurement of atmospheric black carbon using a multi-angle absorption photometer, Environ. Sci. Pollut. R., 7882, 2002.

Schwarz, J.P., Gao, R.S., Spackman, J.R., Watts, L.A. and Thomson, D.S.: Measurement of the Mixing State, Mass, and Optical Size of Individual Black Carbon Particles in Urban and Biomass Burning Emissions, Geophys. Res. Lett., 35, 13810-13814, doi:10.1029/2008gl033968, 2008.

Sharma, S., Brook, J.R. and Cachier, H.: Light Absorption and Thermal Measurements of Black Carbon in Different Regions of Canada, J. Geophys. Res.-Atmos, 107, 4771, doi:10.1029/2002jd002496, 2002.

Please also note the supplement to this comment:

https://www.atmos-chem-phys-discuss.net/acp-2017-686/acp-2017-686-AC1-

supplement.pdf

Interactive comment on Atmos. Chem. Phys. Discuss., https://doi.org/10.5194/acp-2017-686, 2017. 